\title{
Putting Pluralism in its Place $^{1}$
}

\author{
Jamin Asay \\ The University of Hong Kong \\ asay@hku.hk
}

Forthcoming in Philosophy and Phenomenological Research

\begin{abstract}
Pluralism about truth is the view that there are many properties, not just one, in virtue of which things are true. Pluralists hope to dodge the objections that face traditional monistic substantive views of truth (such as the correspondence theory), as well as those facing deflationary theories of truth. More specifically, pluralists hope to advance an explanatorily potent understanding of truth that can capture the subtleties of various realist and anti-realist domains of discourse, all while avoiding the scope problem. I offer a new objection to pluralism that challenges its fundamental commitment to there being a set of alethic properties in virtue of which claims are true. In its place I offer an alternative view that merges standard truthmaker theory with a primitivist conception of truth. This combination of views satisfies the theoretical desires that pluralists claim for themselves, but without taking on pluralism's host of challenges and problems.
\end{abstract}

\section{Introduction}

Pluralists about truth (i.e., alethic pluralists) maintain that truth amounts to different things in different domains. A pluralist may hold, for example, that truth with respect to scientific theories is a kind of correspondence with reality, while moral truth is a matter of coherence with other moral beliefs. Regardless of the particular details of their view, pluralists argue that truth isn't always and everywhere the same, as traditional global approaches to truth have long maintained.

To defend their view, pluralists have cited a number of theoretical considerations that favor pluralism's localized approach to the nature of truth. Pluralists also dodge the dilemma of choosing

\footnotetext{
${ }^{1}$ This paper was first presented at a session on pluralism at the $1^{\text {st }}$ Veritas Philosophy Conference at Yonsei University in Seoul, June 2014. My thanks go to Tim Fuller and Nikolaj Pedersen for the invitation to and organization of the conference, and to all those who attended and offered their feedback. Thanks go also to Derek Baker, Sam Baron, Jeremy Wyatt, and an anonymous referee for their comments on earlier drafts of this paper. Special thanks go to Dorit Bar-On and Keith Simmons, and the members of their seminar on truth at the University of Connecticut in the spring of 2015. The work described in this paper was substantially supported by a grant from the Research Grants Council of the Hong Kong Special Administrative Region, China (HKU 23400014).
} 
either one of the traditional global views (like the correspondence, coherence, and pragmatic theories of truth), or one of the deflationary theories of truth. Both sorts of accounts, inflationary or deflationary, face formidable challenges; pluralists hope to find a middle path that captures the best of both perspectives without taking on their problems.

Of course, pluralism faces its own slew of objections. So even if pluralism can avoid the perils of the traditional inflationary and deflationary views, there is reason to hope for an alternative account of truth. In this paper, I advance a new objection against the pluralist view that challenges its central commitment to there being a collection of alethic properties in virtue of which truths from different domains are true. Many have found this positing of multiple properties to be unwarranted and unnecessary; ${ }^{2} \mathrm{I}$ shall argue that it is independently problematic and objectionable, and makes a critical error in how it understands the metaphysics of truth. I then offer an alternative perspective on truth and truthmaking that captures the key philosophical motivations behind pluralism while avoiding its objections. I begin by presenting the core of the pluralist perspective on truth, and then canvass the three main motivations for the view. I then offer my own set of objections to the pluralist view itself, before concluding with my alternative perspective. The alternative brings together a more traditional perspective on truthmaking along with a commitment to a primitivist conception of truth.

Ultimately, what I aim to offer is an account of the metaphysics of truth that captures all of the fundamental desiderata that pluralists have sought to maintain. So I shall not be disagreeing with pluralists about the basic premises of their argument. Where I differ is that I do not believe that those motivations point directly toward alethic pluralism. Pluralism, again, is motivated by the desire to find an alternative to the traditional substantive and deflationary views about truth that nonetheless captures many of the various phenomena involving truth. My view offers such an alternative, and in a way that avoids the many difficulties facing pluralist theories. Pluralists, and those sympathetic to their major theoretical motivations, have reason to take notice.

\section{Pluralism and its Motivations}

According to its oft-deployed slogan, pluralism is the view that "there is more than one way for a proposition to be true" (Lynch 2004: 384). Truth might sometimes be correspondence, sometimes coherence, sometimes superassertibility, sometimes something else. Pluralism is typically articulated in terms of properties. Nikolaj Pedersen, for instance, defines pluralism as the

\footnotetext{
2 See, e.g., Sainsbury 1996, Haack 2005, Blackburn 2013, and Dodd 2013.
} 
view that there "are several properties [...] in virtue of which propositions are true" (2012: 588; see also Pedersen and Wright 2013: 2). How these different truth properties relate to one another is a matter of internal dispute among pluralists. For Michael Lynch (e.g., 2009), truth is a single functional property that is multiply realized by a variety of other properties in different domains. Truth is thus both "one" and "many". Each of those properties is able to make truth-bearers true in virtue of their fulfilling a certain functional role. Gila Sher (2004) argues that truth is always a matter of correspondence, but that the nature of correspondence varies from domain to domain (see also Barnard and Horgan 2006). Still other pluralists argue that there is no general truth property shared by all and only truths; instead, there is just the collection of alethic properties that make truth-bearers true in different domains (e.g., Cotnoir 2013).

More vital for my purposes is not what pluralists disagree about, but what they agree upon. The shared core thesis of pluralism is that truth-bearers are true in virtue of their instantiating an alethic property, of which there are several. Pluralists are also united with respect to the central motivations behind the view. Three motivations in particular generate the most discussion, and serve as the main pillars in the pluralists' overall argument. First is what Lynch refers to as the scope problem: "This is the challenge of saying what is in common between all truths, no matter what their subject. Theories that seem plausible when applied to propositions about the physical world around us (such as the causal/referential theory) are less plausible when applied to propositions about numbers, or norms" (2006: 63). The scope problem has a long history. G. E. Moore once casually noted that truth in general cannot be defined in terms of a relation to reality because there's nothing in reality for mathematical truths to correspond to (1899: 180). (At the time, Moore was led by this and other related considerations to think of truth as an undefinable primitive.) The scope problem trades on the great diversity of truths. It's true that eleven is prime, it's true that an oxidant is necessary for combustion, and it's true that slavery is immoral. Faced with such a heterogeneous collection, it's plausible to suppose that different properties are responsible for these very different truths. Other views must show how truths about physics, mathematics, morals, and others are made true in the same way, despite potentially having very different metaphysical bases. The scope problem suggests that any candidate monistic truth property will fail to plausibly apply to every last truth.

A second core motivation for pluralism derives in large part from Crispin Wright's pioneering work on truth and objectivity (1992). Wright argues that a pluralistic perspective on truth can be put to work in developing a nuanced understanding of realism and anti-realism about various philosophical domains. Suppose one thought that commitment to a correspondence theory of truth brought along a realist metaphysical perspective in tow. (For, on this view, to be 
true just is to correspond to reality.) A globalist about the correspondence theory would then be committed to realism about any domain in which truth appears. To be an anti-realist about some domain of discourse, then, one must turn to some form of non-cognitivism or error theory, which can be difficult views to defend. Wright's proposal is that localized perspectives on realism can be sustained by adopting localized perspectives on truth, and theorists can thereby avoid being forced into thinking that truth cannot appear in anti-realist domains. Realist domains of thought, on Wright's proposal, operate with different conceptions of truth than are employed by anti-realist domains. Facts in realist domains, for instance, exhibit greater explanatory power (what Wright calls "width of cosmological role"). Furthermore, it could be that statements that express those facts, if superassertible (a form of warrant that would survive all improvement to one's information), are superassertible in virtue of being true. Facts in anti-realist domains manifest less explanatory reach, or perhaps statements that express them are true in virtue of being superassertible. For those who prefer localized perspectives on realism (such as, for example, advocating realism about science but anti-realism about aesthetics), pluralism offers a way of articulating the differences between realist and anti-realist domains of thought without having to resort to non-cognitivism or error theory.

A final motivation for pluralism is avoiding the perils of deflationism. According to deflationary theories of truth, truth is neither a metaphysically substantive property, nor of any explanatory use when it comes to other projects in philosophy. For deflationists, truth is merely an expressive device, not an explanatory tool (e.g., Horwich 1990 and Williams 1999). ${ }^{3}$ Truth is a device that lets one express, among other things, what would otherwise involve infinitely long conjunctions and disjunctions. For example, instead of asserting that if Kant said that raccoons are running rampant in Russia, then raccoons are running rampant in Russia, and if Kant said that puffins prefer pickled pickerel, then puffins prefer pickled pickerel, and so on, I can simply assert that everything that Kant said is true. Furthermore, I can use 'true' to assert or endorse what someone else has said without repeating it. I can proclaim that what my honest Hungarian hostess has just said is true, even though I, ignorant of the Hungarian language, may not know the content of what she has just said. According to deflationists, truth's raison d'être lies entirely in these and other similar expressive functions; there is no philosophical project of explaining truth that needs to resort to finding some common alethic property uniting the set of truths.

Because deflationists deny the explanatory potency of truth, they are not able to make use of the concept (beyond its expressive functions) in giving analyses of other philosophically

\footnotetext{
${ }^{3}$ But see Horsten 2011, chapter 7.
} 
important concepts, such as belief, assertion, and meaning. It is commonly thought, for example, that deflationists cannot avail themselves of a truth-conditional theory of meaning (lest they give the lie to their view that truth has no explanatory connections to other concepts) (e.g., Bar-On, Horisk, and Lycan 2000). Horwich, for one, accepts this consequence, and defends a "use" theory of meaning instead (1998). Another contentious issue concerns whether or not deflationists can account for the forms of normativity that are associated with truth. Wright $(1992,1999)$ and Lynch (2009: 111-114) argue that this spells trouble for deflationists: truth thought of merely as an expressive device cannot explain how what we believe and what we assert to be true are governed by various norms. Deflationists, naturally, disagree (e.g., Horwich 2006). These matters, of course, cannot be settled here. But for those who are not convinced of the explanatory impotency of truth, deflationary views are unattractive. Pluralism, which offers a substantive account of truth, does not need to treat truth as an explanatorily vacuous notion, and so pluralists can employ it when confronting other philosophical projects. As Lynch writes: "Explaining meaning, or content determination for example, is hard enough without requiring that we don't appeal to truth" (2009: 114).

These three motivations for pluralism together form a general argument in favor of the pluralist conception of truth. The traditional and most widely discussed views of truth include the various monist views (such as the correspondence, coherence, pragmatic, and epistemic accounts) and the various deflationary views (such as Horwich's minimalism, prosententialism, and others). The former face the scope problem and have difficulty accounting for localized perspectives on realism. The latter face explanatory deficiencies. To satisfy all three desiderata, then, we must look to an alternative view about truth, and that is precisely what pluralism provides. It is a substantive, and therefore explanatorily useful, account of truth which can accommodate realist and anti-realist perspectives while dodging the scope problem. Pluralism thus enjoys a substantial theoretical advantage over its main competitors.

What this argument for pluralism presupposes, however, is that pluralism is the option left open once the traditional substantive and deflationary views are set aside. If there are alternative views that also satisfy the pluralist desiderata, then the argument equally favors those views. In the next section, I offer a new objection to pluralism that should compel us to seek out such an alternative view, one that agrees with pluralism about the problems facing the theory of truth, but that disagrees with the pluralist solution. 


\section{Challenging Pluralism}

3.1. The objection to alethic pluralism

Despite its significant attractions, pluralism has faced a substantial number of challenges. The problem of mixed inferences (Tappolet 1997) questions how pluralists can make sense of the validity of arguments that involve premises drawn from domains with different truth properties. Related problems involve understanding the kind of truth that applies to compound truths that are formed from atomic truths belonging to domains with different truth properties (Tappolet 2000), and understanding the kind of truth that applies to atomic truths that involve multiple domains (Sher 2005, Wyatt 2013). Pluralists also face the challenge of how to individuate the domains to which different alethic properties apply (Wyatt 2013), and of doing so in a way that doesn't collapse into the view that each individual truth has its own individual truth property (Jarvis 2012). Finally, pluralists face the possible outcome that they inherit all the problems facing other views, since pluralism adopts elements of several different theories of truth whose shortcomings are well known (Wright 2012).

In response to these criticisms, pluralists have generated a multitude of responses and variations of the view (e.g., Lynch 2009 and 2012, Pedersen 2010, and Edwards 2011). I shall set aside these more familiar objections and direct my criticisms at a more foundational aspect of pluralism. My interest is in challenging the very idea of a truth-bearer being made true by its possession of an alethic property. The pluralist picture is one according to which there are multiple alethic properties that serve the primary responsibility of making truth-bearers true. This sort of view, I argue, misunderstands the metaphysical considerations surrounding truth. Rather than there being several alethic properties that are responsible for making claims true, there are in fact none. What accounts for why truth-bearers are true is the world's stock of truthmakers: its total ontological inventory, not some set of potent alethic properties. Pluralists, I contend, have mistaken the vast heterogeneity in the set of truths as evidence of a plurality of truth properties. In the next section, I propose an alternative understanding of the plurality of truths: the heterogeneity of truths is best accounted for by the diversity of truthmakers, not truth properties.

What alethic pluralism offers is a view according to which what it is to be true is to be made true by one of several alethic properties. Pluralism's commitment to a set of alethic properties that play a foundational truthmaking role is well documented. Douglas Edwards writes that "According to the alethic pluralist, there will be a robust property in virtue of which the propositions expressed by sentences in a particular domain of discourse will be true, but this 
property will change depending on the domain we are considering” (2011: 31). Similarly, Lynch describes his view by writing: "Propositions about different subjects can be made true by distinct properties each of which plays the truth-role" (2009: 77). On the pluralist picture, then, there are various domains of discourse, which are sets of truth-bearers. For any given domain, the true truthbearers in that domain are true in virtue of their possessing the particular alethic property that plays the truth role for that domain. A fully developed pluralist theory articulates how domains are individuated, specifies the property that is operant as the alethic property in each domain, and explains how the various truth properties relate to one another (if indeed they do; recall that while all pluralists think that truth is "many", not all agree that it is also "one").

Note the pluralists' language of truth-bearers being true "in virtue of" having one of the truth properties, or being "made true" by those properties. This is no accident. The pluralists' idea is that there are a variety of alethic properties that are in some sense "responsible" for the truth of truth-bearers. It's not a brute fact that certain sentences, propositions, and beliefs are true. Rather, truth-bearers are true in virtue of certain metaphysical states of affairs obtaining; they are true because of what's going on out in the world. What is distinctive about pluralists is that they take a central ontological ground of the truth of truth-bearers to be their instantiation of certain alethic properties. The basic idea is simply that the truth of truth-bearers is accounted for, "grounded" by, or "made true" by a variety of different properties, depending on the domain to which the truth-bearer belongs. By contrast, the traditional monistic theories identify a single property (correspondence or coherence, say) as the property that grounds or makes truth across the board. This pluralist picture of how truth-bearers are made true sharply contrasts with standard conceptions of truthmaking (e.g., Armstrong 2004). On that view, it is objects (be they ordinary particulars, tropes, states of affairs, or whatever it is that happens to exist) that make truth-bearers true, not alethic properties. The importance of this difference will emerge below.

The pluralist idea that truth-bearers are true in virtue of their possessing certain properties has a natural appeal. In fact, understanding truth in this way appears to run parallel with a standard way of thinking about other kinds of property possession. For example, Socrates, Plato, and Aristotle were all philosophers. These three shared the same property, and it's that one shared property that explains why they all shared something in common by being philosophers. Hence, Socrates was a philosopher in virtue of his possessing the property of being a philosopher (whatever that ultimately amounts to), which is the same property that Plato and Aristotle also instantiated. By contrast, Protagoras, Gorgias, and Thrasymachus all shared a different property, that of being a sophist, which explains what binds them together. There are, of course, a variety of ways of understanding the metaphysics of properties, but the internal disputes surrounding the 
ancient debate over realism and nominalism need not concern us here. What does matter is that properties are being appealed to in order to perform some metaphysical labor (accounting for resemblance, for example), regardless of whether one explicates that labor in terms of truthmaking, grounding, or something similar, and whether one understands properties in terms of universals, tropes, natural classes, or something similar.

Notice, then, the parallel to which a pluralist might call our attention. Socrates is a philosopher. What's going on here, metaphysically speaking, is that a particular object, Socrates, is instantiating a property, being a philosopher. Note also that the truth-bearer $<$ Snow is white $>$ is true. ${ }^{4}$ What's going on here, metaphysically speaking, is that a particular object, $<$ Snow is white $>$, is instantiating an alethic property, $X$. What exactly that property is in this case (say, corresponding to the facts) might differ from the property instantiated by $<$ The torture of turtles is intolerable $>$, or the property instantiated by $<\mathrm{e}^{\pi i}=-1>$. But it's this alethic property, whatever it turns out to be, that accounts for why $<$ Snow is white $>$ is true, just as the property being a philosopher accounts for why Socrates is a philosopher.

The parallel, however, is illusory. To see why, notice that in accounting for Socrates's being a philosopher by way of Socrates and being a philosopher, we are already accounting for the truth of something, namely, <Socrates is a philosopher $>$. Explaining Socrates's being a philosopher just is explaining < Socrates is a philosopher>'s being true. There are not two separate and metaphysically distinct states of affairs here that need analysis: to posit two distinct states of affairs is ontological overkill. Once we have given a metaphysical account of how it is that Socrates is a philosopher, we have already offered a metaphysical account of how it is that $<$ Socrates is a philosopher $>$ is true. To think otherwise is to impose an unnatural and unnecessary gulf between two ways of describing the same thing.

To spell out this objection more concretely, suppose (merely for illustrative purposes) an Armstrongian approach to truthmakers (see Armstrong 2004). What makes contingent predications like $<$ Socrates is a philosopher $>$ true are states of affairs, which are non-mereological composites of particulars (Socrates) and universals (being a philosopher). Because the state of affairs composed by Socrates and being a philosopher exists, $<$ Socrates is a philosopher $>$ is true. Similarly, because the state of affairs composed by Plato and being a philosopher exists, <Plato is a philosopher $>$ is true. There is no state of affairs that joins Gorgias and being a philosopher, which is why $<$ Gorgias is a philosopher $>$ fails to be true. Hence, the truthmaker for $<$ Socrates is a philosopher $>$ is a state of affairs, an important component of which is the property being a

\footnotetext{
${ }^{4}$ I typically use ' $\langle p\rangle$ ' to refer to the proposition that $p$, though it could just as well refer to any truth-bearer whose content is given by ' $p$ '.
} 
philosopher. But what we don't need to make the proposition true is a further property being true (or any of the alethic properties that are offered to realize or manifest being true) belonging to the proposition. Such a property would be ontologically otiose.

In short, my objection is that propositions like $<$ Socrates is a philosopher $>$ are true not in virtue of the proposition's instantiating something like corresponding to the facts, as the pluralist maintains, but rather that it's true in virtue of Socrates instantiating being a philosopher. Properties may have an important role to play as truthmakers for truth-bearers, but there is no need for any distinctly alethic properties to perform that role. The non-alethic properties handle the truthmaking job all by themselves. Note that this view does not deny that $<$ Socrates is a philosopher $>$ is true, or-and what amounts to the same thing - that it instantiates being true (when understood as an abundant property, in the terminology of Lewis 1983). Rather, the view maintains that what grounds $<$ Socrates is a philosopher $>$ 's being true is the state of affairs involving Socrates and being a philosopher, not some alethic property. Put differently, while the view doesn't deny that there is some sort of property of truth that true truth-bearers instantiate, it does adamantly deny that the property of truth is a metaphysically substantive property responsible for making truth-bearers true. Truth is not an "alethically potent" property, to borrow the language of Pedersen and Wright (2013: 2). $<$ Snow is white $>$ isn't true because $<$ Snow is white $>$ instantiates being true, but because snow instantiates being white. It's the non-alethic properties together with the particular objects in the world that make truth-bearers true. In the language of sparse and abundant properties (see Lewis 1983), being true and any proposed alethic property are merely abundant properties, not sparse properties of the sort that are responsible for accounting for truthmaking and other metaphysical tasks.

To push the point even further, note that when it comes to some truths, no properties at all, alethic or not, need to be invoked in one's truthmaking account. Socrates himself can serve as a truthmaker for truth-bearers such as $<$ Socrates exists $>$ and $<$ There are humans $>$. There is no need to invoke a state of affairs or any property of any kind, let alone an alethic property, to account for these truths. By contrast, the pluralist must contend that $<$ Socrates exists $>$ is true in virtue of its possessing a property like corresponding to the facts. This account strikes me as being both implausible and unnecessary. It's true that Socrates exists because a certain person, Socrates, exists. Because he exists, the truth-bearer is true. It's not the case that it's true that Socrates exists because a certain truth-bearer carries a certain alethic property. Plus, the pluralist's offered truthmaker is simply unnecessary. The existence of Socrates is not in question, ontologically speaking, and he is a perfectly sufficient truthmaker for the truths in question. Whether there are metaphysically potent alethic properties is, however, an ontologically contentious matter, and an essential 
commitment of pluralism. Given that there are ontological resources available for finding the grounds for truths that do not require pluralism's contentious posits, there is little reason for adopting the pluralist's metaphysical program.

\subsection{Some pluralist responses}

My basic objection, then, is that pluralists offer a misguided view as to what makes propositions true. Their commitment to a set of metaphysically potent alethic properties is ontologically unnecessary and therefore unjustified. There are a variety of responses that pluralists might push in response to this objection. First, one might point out that while the state of affairs composed by Socrates and being a philosopher may be a sufficient truthmaker for $<$ Socrates is a philosopher>, so too is the state of affairs composed by <Socrates is a philosopher $>$ and its relevant alethic property. And, importantly, it is not objectionable to provide multiple truthmakers for a single truth. After all, everyone typically agrees that the truthmaking relation is not one-one: Socrates is a truthmaker for many truths, and truths like $<$ There are humans $>$ find a truthmaker in each and every human. So the fact that the pluralist has an extra truthmaker on hand is in and of itself no objection to the view.

While this observation about multiple truthmakers is correct, it does not blunt the force of the objection. The pluralist advocates the existence of metaphysically potent alethic properties, and one should not, on grounds of ontological parsimony, posit such things unless there is sufficient reason to do so. My argument is that alethic properties do not earn their keep by way of truthmaking considerations, which seems to be their primary role on the pluralist's picture. Given that perfectly ontologically respectable entities are on hand to ground the truth of propositions, there is no need to look further to a set of alethic properties. Perhaps their existence is not in and of itself objectionable. ${ }^{5}$ Still, the issue is simply that they are an unnecessary posit, and so parsimony compels us to reject them.

Another concern might be that my argument does not generalize for all truths. Perhaps we can explain why $<$ Socrates exists $>$ and $<$ Socrates is a philosopher $>$ are true without appealing to alethic properties, but what about the contentious cases that help motivate pluralism in the first place? What are the truthmakers for $<$ Giving to charity is morally good $>$ and $<$ There is exactly one even prime number $>$ ? For those who are ontologically suspicious of moral properties and Platonic entities, the pluralist's alethic properties might be of some use. For instance, perhaps the

\footnotetext{
${ }^{5}$ But see Asay 2014.
} 
truthmaker for <Giving to charity is morally good> involves, as on Lynch's account, its instantiating the property being concordant, where being concordant is a matter of being coherent in a certain system and staying coherent through any improvements to that system (2009: 176). Similarly, Crispin Wright suggests that moral truth is a matter of superassertibility, which is to say that moral truth amounts to being warranted in a way such that the warrant would withstand any further improvement to our information (1992: 48). When it comes to mathematical truths, the pluralist again might take the upper hand by having certain alethic properties in stock to do the work for which others require Platonic entities.

In response, it's important to note first that I do not take myself to have shown that nothing in the neighborhood of an alethic property equipped with truthmaking powers ever exists. If someone defends the view that the truthmakers for moral claims all indispensably involve a property like superassertibility, then that is a possible position one might hold regarding moral truthmakers (though I would hesitate to call this a view of moral truth, since that phrase implies that there are different kinds of truth that are always constituted by some alethic property or other). But the pluralist must defend a much stronger view. The pluralist's view is that all truths are true in virtue of their possessing some alethic property or other; they aim to offer a view as to what truth itself is. To think that superassertibility is responsible for truth in the moral domain, but that no alethic properties operate in other domains, is not a kind of pluralism about truth. Instead, it's a metaethical view as to what is responsible for the truth of moral judgments. Hence, even if pluralists have a good account of what makes moral judgments true (which I doubt on independent grounds that I won't go into here-see Asay 2013b), it doesn't follow that they thereby have defended pluralism.

It's useful in this context to think of alethic pluralism as offering a view of what truth is by way of telling a pluralist story about what the truthmakers are in different domains, a story that features a plurality of alethic properties up front and center. My main objection has been to the pluralist's account of truth itself: I argue against their view that what it is to be true is to be made true by one of the several alethic properties. But in general, theories of truth need not bring along assumptions about truthmaking in tow. In giving a theory of truth, one does not necessarily give a theory of truthmaking (and vice versa). (This, I take it, is one of the most crucial insights about truth that deflationary theories have brought into clear focus.) As a result, one could accept some of what pluralists suggest regarding truthmakers while rejecting their theory of truth. I happen to find both aspects of their view to be false, but one could agree with me on the latter while finding something more salvageable in the former. 
Finally, one might suspect that my objection has traded repeatedly on a particular conflation. Yes, Socrates is the truthmaker for the claim that Socrates exists. But what the pluralist wants to explain is not why Socrates exists, but why $<$ Socrates exists $>$ is true. It's claims of this latter sort that a theory of truth like pluralism is interested in explaining. Alethic properties have their role to play in explaining the truth of truth-bearers, and not non-alethic matters such as whether or not Socrates exists.

There are a number of problems with this point of view. First, it doesn't fit with the pluralist's ambitions. The response, in effect, distinguishes a truth-bearer $\langle p\rangle$ from the "semantically ascended" truth-bearer $\langle<p\rangle$ is true $>$, and argues that alethic properties are relevant to the analysis of the latter only. But this move concedes too much. The pluralist wants to explain all truths, including the truth of $\langle p\rangle$ itself, and not just the truth of $\langle<p\rangle$ is true $>$. The goal is to show that what makes $<$ Snow is white $>$ true is different from what makes $<$ Slavery is immoral $>$ true. The pluralist needs to give an account of the truth of all truth-bearers, and not just those semantically ascended ones that make explicit reference to truth-bearers and truth. ${ }^{6}$

A more fundamental problem with this response, however, is that it posits too large a chasm between $\langle p\rangle$ and $\langle\langle p\rangle$ is true $\rangle$. Some might maintain that these two truth-bearers are actually identical. That's not obvious, given that only the latter seems to be ontologically committed to a truth-bearer. Those who are suspicious of propositions, for example, might happily assert 'Propositions don't exist', but refrain from asserting 'The proposition that propositions don't exist is true', on account of what they take to be its non-referring expression. But even if the two truthbearers are different, one should be skeptical of any view that posited radically different truthmakers for the two. Pluralists who endorse a strong separation here will presumably detect different truthmakers as well. For example, while the state of affairs of Socrates's being a philosopher is a truthmaker for $<$ Socrates is a philosopher $>$, that proposition itself together with an alethic property is the truthmaker for $<<$ Socrates is a philosopher $>$ is true $>$. The pluralist utilizing this reply needs both, since if the former is sufficient for both truths, then the alethic property is gratuitous. If the latter is sufficient for both, then alethic properties are too powerful: they can make truth-bearers true just with the help of propositions, and no "worldly" contribution.

\footnotetext{
${ }^{6}$ Pluralists may reply here that their theory is intended to explain only why being true applies to, for example, $<$ Snow is white $>$, but not to explain why snow is white. This response gives up too much, as it will then be unclear why the forthcoming explanation for why snow is white does not thereby also explain why being true applies to $<$ Snow is white $>$. In effect, this response leaves too little work for alethic properties to do-work which happens to be work that the non-alethic properties are able to do themselves (as I argued above).
} 
But is there reason to posit separate truthmakers here? Necessarily, $\langle p\rangle$ and $\langle\langle p\rangle$ is true $>$ share the same truth value. As a result, it would surprising if they turned out to have quite distinct truthmakers. Suppose $\mathrm{X}$ is the class of truthmakers for $\langle p\rangle$, and $\mathrm{Y}$ is the class of truthmakers for $\langle\langle p\rangle$ is true $\rangle$. Given that, necessarily, if one of the pair is true, so too is the other, then the existence of one member of $\mathrm{X}$ necessitates the existence of some member of $\mathrm{Y}$, and vice versa. If the members of $\mathrm{X}$ and $\mathrm{Y}$ are distinct existences, then this perspective requires there to be necessary connections between distinct existences, a consequence that (by my lights, anyway) should be avoided if possible. Positing such connections imposes greater structure on reality, and so considerations of parsimony again suggest against committing to such connections unless absolutely necessary. Suppose, then, that the members of X and Y aren't distinct. In that case, there are no grounds for thinking that something extra needs to be around (such as a metaphysically potent alethic property) for making $\langle<p\rangle$ is true $>$ true that isn't already accounted for by the truthmakers for $\langle p\rangle$.

The better view is that whatever it is that makes true $\langle p\rangle$ also makes true $\langle\langle p\rangle$ is true $\rangle$ (with, perhaps, the proviso that the truth-bearer itself will figure into the truthmaker for the latter only). If the state of affairs (call it 'A') composed by Socrates and being a philosopher is a truthmaker for $<$ Socrates is a philosopher $>$, then it is a truthmaker for $<<$ Socrates is a philosopher $>$ is true $>$. If one maintains that the latter is made true by a different state of affairs-one composed by the truth-bearer and some alethic property (call it 'B')-then one faces the question as to how A and B are related. If $\mathrm{A}$ and $\mathrm{B}$ were completely separate from one another, they should be able to exist independently of one another. In that case, <Socrates is a philosopher $>$ could be true while $<<$ Socrates is a philosopher $>$ is true $>$ is false (and vice versa), which is a metaphysically impossible scenario. It could be that B's existence completely depends upon A's, but in that case the question would arise as to why anyone should take on the extra ontological commitment to $\mathrm{B}$, given that $\mathrm{A}$ is all we need to account for the truth of both truth-bearers. More to the point, it undermines the pluralist's basic suggestion that it's B that's responsible for the truth of $\langle<p\rangle$ is true $>$, since A is what's doing all the work. Finally, it could also be that A depends on B for its existence. While this would earn ontological respectability for B, it would come at the cost of something approaching idealism. On this view, the primary states of affairs are truth-bearers having alethic properties, and they ground other objects having other properties. In this instance, because < Socrates is a philosopher> instantiates being true, Socrates instantiates being a philosopher. Most realist-minded philosophers see things the other way around: the truth-bearer instantiates being true because

\footnotetext{
7 This consequence follows on any view of truthmaking (such as Armstrong's) that accepts an entailment principle, such that where $\langle p\rangle$ entails $\langle q\rangle$, any truthmaker for $\langle p\rangle$ is a truthmaker for $\langle q\rangle$.
} 
Socrates instantiates being a philosopher. At the least, pluralists shouldn't commit themselves to such an idealistic perspective from the outset, especially given their usual intent of preserving realism about some domains.

\section{An Alternative to Pluralism}

I have now explained what I find to be problematic about the pluralist position. Nevertheless, I hope that pluralists will find my proposed alternative compelling. Not only does it capture the three basic desiderata driving pluralism, it also adheres to the basic slogan of pluralism. Pluralism's guiding thought, recall, is that there is more than one way for a proposition to be true. In this section, I present an alternative understanding of that thought that captures the central motivations behind pluralism while abandoning its commitment to a class of alethic properties. Importantly, this perspective shares pluralism's distrust of deflationism, and so speaks to the same set of theoretical considerations that have led so many to the pluralist camp. ${ }^{8}$

The first key component of the alternative is to embrace pluralism's basic appeal to truthmaking (i.e., to truths being true in virtue of something else), while locating the truthmakers in the broader ontological inventory of the world, and not a class of alethic properties. As we have seen, traditional theories of truthmaking make use of ordinary objects (like Socrates), as well as more contentious ontological posits such as properties or universals, and states of affairs. Other truthmaker theories make use of tropes (e.g., Lowe 2007), while some aim for truthmakers that are fully compatible with robust forms of nominalism (e.g., Lewis 2001 and 2003). These approaches to truthmaking seek to find a satisfying ontology to fully ground everything that's true about the world; at no point have any of them resorted to alethic properties. For standard truthmaker theory, which truth-bearers instantiate truth depends on what's going on in the world, ontologically speaking. The alethic properties aren't themselves doing the truthmaking work; instead, we explain the presence of truth by way of the world's ontology.

In standard truthmaker theory, then, we find an immediate commitment to the idea that truth-bearers can be made true in a variety of ways. The truthmaker for $\langle p\rangle$ may be radically different from the truthmaker for $\langle q\rangle$. Socrates might be the truthmaker for the former; the latter's truthmaker could involve some combination of laws of nature, dispositional properties,

\footnotetext{
${ }^{8}$ It is an open question as to just how much of my critique of pluralism from section 3 deflationists can take on board. My objection is committed to substantive claims about truthmaking, and there is ongoing dispute as to whether deflationists can or should accept views about truthmaking. Thomas (2011) argues that deflationism and truthmaking are incompatible (see also MacBride 2013), whereas Lewis (2001) and I (Asay 2013a) argue to the contrary.
} 
and ordinary objects (if $\langle q\rangle$ is, say, a counterfactual claim about what would happen if a baseball were to strike a particular window). The job of finding truthmakers is just as difficult a job as is determining what belongs to the world's ontology. There's no simple or formulaic answer to the question 'What's the truthmaker?' that applies to each and every truth. The set of truthmakers is as diverse as is the world's inhabitants. Here, I contend, is the proper place for pluralism. The reason that there is such diversity in the realm of truths, and what makes truths true, is that the world itself a vastly diverse place, including everything from apples to quarks to zebras. Indeed, there are many, many ways for something to be true. ${ }^{9}$

The truthmaker theorist's approach to finding the grounds for truths, as a result, does not face the scope problem. There is no single entity, or even kind of entity, that has to play a truthmaking role across the entire range of truths. Furthermore, truthmaker theory is also prepared to handle a subtle, localized interpretation of realism debates (see Asay 2012). It can offer, in effect, a metaphysical account of realism that relies on different kinds of truthmakers which runs closely parallel with Wright's more semantic account that relies on different conceptions of truth. According to a truthmaker approach to realism, whether or not a domain is best understood realistically is a matter of what sort of reality (as offered by a theory of truthmakers for that domain) is grounding the truths (if any) of that domain. The character of the truthmakers for a given domain helps to explain our judgments as to whether the domain is realist or not. For example, realist perspectives on science will maintain that a mind-independent external world as literally described by scientific theories is what makes those theories true (and not merely a world of observable objects, say). Metaethicists divide as to what makes moral judgments true: is it a set of genuinely non-natural moral properties, some perfectly natural properties, the social conventions operant in a particular society, or something else? The truthmaker theorist argues that questions about realism and anti-realism can be answered in this ontological way, by trying to understand the metaphysical grounds for moral truths, scientific truths, and the rest. Realism debates need not turn on what particular property of truth is operating in that domain. Truth, according to this alternative perspective, really has nothing to do with it. There are as many ways to be true as there are truths. ${ }^{10}$

\footnotetext{
${ }^{9}$ My view should not be confused with Griffith's (2015) recent pluralism about truthmaking itself. Griffith advocates the view that there is a plurality of truthmaking relations (and is motivated more by issues internal to truthmaker theory than those that drive alethic pluralism). My contention is that "orthodox" truthmaker theory (and its commitment to just one kind of truthmaking) is already sufficient for explaining how there is "more than one way of being true".

${ }^{10}$ In saying this, I do not thereby align myself with Jarvis's "maniacal” pluralism (2012), which contends that every individual truth is made true by its own unique alethic property. On Jarvis's view, truths are always made true by alethic properties, and there are as many alethic properties as there are truth-evaluable contents. On my view, truths are never
} 
As with pluralism, it's what makes a given proposition true that is relevant to realism. But, I contend, that thought is already better captured by standard truthmaker theory, which has no need of metaphysically potent alethic properties. ${ }^{11}$

The truthmaking approach, then, offers a way of showing how the truths of some domains are made true in a realism-relevant way, and the truths of other domains in an anti-realism-relevant way. ${ }^{12}$ Attending to truthmakers does not, however, only provide an account of the differences between domains. It also provides the resources for understanding the similarities within domains (another goal lauded by some pluralists). For example, the set of ethical truths-at least according to some metaethical views - are made true not by any kind of mind-independent reality, but rather by sets of social conventions and practices. The various truthmakers for ethical truths will resemble each other in a way that will set them apart from the mind-independent truthmakers for, say, physical theories. Truthmaker theorists look to the similarities in truthmakers in accounting for the similarities between truths. Again, the similarities will be due to the ontology grounding the claims in question, not the kind of truth that they enjoy. Although the details must be left to the further development of the truthmaking account of realism, the basic point is simply that truthmakers can in principle provide the same basis for unification that pluralists find in their various alethic properties.

So far, the alternative I have sketched is in some ways reminiscent of certain deflationary responses to pluralism (e.g., Blackburn 2013 and Dodd 2013). Deflationists maintain that $<p>$ 's truth has to do with whatever $\langle p\rangle$ is about, and $\langle q\rangle$ 's truth has to do with whatever $\langle q\rangle$ is about. There need not ever be a common story to be told about the truth of any two truth-bearers. In this way, deflationists can avoid the scope problem while acknowledging that there are a variety of ways that things are made true. When it comes to the differences between, say, moral discourse and scientific discourse, there is no need to see the difference as involving the kind of truth operant in the two domains; rather, the difference is instead found in the differing content of the two domains (Sainsbury 1996: 900, Haack 2005: 89-90, Blackburn 2013: 265, Dodd 2013: 305). To see

made true by alethic properties, and a truthmaker for some truth may very well be a truthmaker for other (perhaps infinitely many other) truths.

11 Sympathetic perspectives to the one I offer here might be found in Sainsbury (1996) and Haack (2005 and 2014), though they do not develop their ideas as systematically in terms of truthmaking as I am advocating here.

${ }^{12}$ As a result, my view may endorse what Pedersen (2014) calls "metaphysical pluralism", though I resist putting much theoretical weight on the notion of "ways of being". I differ from Pedersen in thinking that this non-global perspective on realism gives support for alethic pluralism. On my view, the diversity found in the world makes further diversity in the property of truth otiose. 
the difference as a difference in both content and truth is to commit the error of "double counting" (Blackburn 2013: 265).

While I am sympathetic to various dimensions of the deflationist platform (most notably its rejection of the need for metaphysically potent alethic properties), there remain important differences between the deflationary view and my own that are worth highlighting. First, deflationary theories of truth are silent on the topic of truthmaking. ${ }^{13}$ A deflationist may say, for example, that $<$ Snow is white $>$ is true in virtue of snow being white, and not in virtue of $<$ Snow is white $>$ instantiating the alethic property corresponding to the facts. That may be so, but it is ontologically unilluminating. ${ }^{14}$ What are the ontological grounds for snow being white-is it the existence of a state of affairs, trope, or some alternative? Does it even require any ontological ground at all? Deflationists (qua deflationists) offer no answer to the question of what the ontological grounds are for the truth of propositions. It is always an open, metaphysical question what the truthmaker is for $<$ Snow is white $>$, even though we can all agree that $<$ Snow is white $>$ is true if and only if snow is white.

Being a theory of truth, deflationism is under no immediate obligation to give a theory of the ontological grounds for truths. But this inherent metaphysical neutrality reveals that deflationism qua deflationism is not suited for articulating the ontologically substantive differences between different domains of thought. By taking on partisan metaphysical views, pluralists and truthmaker theorists have the resources for articulating why realist attitudes might be appropriate for some domains, but not others. If deflationists also want to capture those differences, they must do so via other theories that go beyond their deflationism. This shortcoming is not in and of itself an objection to deflationism; it just goes to show how deflationary theories need supplementation if they are to compete with pluralist and truthmaking theories. Dodd, for instance, believes that deflationists can avail themselves of Wright's account of realism and anti-realism, provided that it is shorn of its commitment to multiple truth properties (2013: 313). Blackburn endorses an approach to realism debates that employs an expressivist-cum-pragmatist strategy (2013: 270-273). In point of fact, then, neither Dodd nor Blackburn takes on the truthmaking approach to realism. Still, whether a deflationist could in principle also take on a robust commitment to truthmaker

\footnotetext{
13 At least on my view. See again footnote 8.

14 I find Jarvis's maniacal pluralism (2012) similarly unilluminating. He gives a recipe for reading the ontological grounds for any truth content right off of the content. The truthmaker for $\langle p\rangle$ is the property being such that $p$ and the truthmaker for $\langle q\rangle$ is the property being such that $q$. No truthmaker theorist accepts that ontological analysis is so easily uncovered. Nor do I take such properties to be "sparse", as Jarvis presumably does if he is to regard them as alethically potent.
} 
theory is a contentious issue that we need not take up here. ${ }^{15}$ So long as some account of realism and anti-realism is available to deflationists, they can meet pluralism's second desideratum.

The upshot is that deflationists face no difficulty with the scope problem, and (pending the compatibility of deflationism with some account or other of realism) can handle the differences between realist and anti-realist domains of thought (though not by way of their theory of truth). This observation is not new to the ongoing dialectic between pluralists and their opponents. Dodd is clear that he believes deflationists can maintain the first two motivations behind pluralism without taking on its contentious and problematic commitments. Lynch himself appears to concede that deflationists don't face the scope problem (2009: 4), as it is more immediately a problem for the substantive monistic views. But recall that a third motivation driving pluralism is the desire to avoid having to take on a deflationary account of truth. Obviously, deflationists and pluralists disagree as to whether avoiding deflationism is an appealing desideratum, and this paper is not the place to evaluate the independent merits and challenges of deflationism. ${ }^{16} \mathrm{I}$ have been assuming, alongside pluralists, that the explanatory challenges facing deflationism are sufficient for motivating an alternative, should an acceptable one be available. What remains to be seen is what sort of non-pluralist view manages to capture all three pluralist motivations.

The reason such a view is not readily apparent is that pluralists, as well as their deflationary and inflationary opponents, have suffered from dialectical myopia. The general pluralist argument discussed earlier suggests that the scope problem and nuanced approaches to realism and antirealism tell against the traditional monistic views of truth, and that the explanatory fecundity of truth challenges traditional deflationary views. Pluralism emerges from this state of affairs as the superior view only if the options on the table are limited to traditional monism, deflationism, and pluralism. But another contender remains dialectically open: the primitivist conception of truth long advocated by Davidson (e.g., 1996), and more recently defended by Patterson (2010) and myself (Asay 2013a).

According to the primitivist conception of truth, truth is an indefinable conceptual primitive. That is to say, the concept of truth cannot be defined, without circularity, in terms of other concepts (like correspondence, coherence, or assertibility). Taking truth as primitive is

\footnotetext{
${ }^{15}$ Dodd, for one, is an outspoken critic of truthmaker theory (e.g., 2002 and 2007). Blackburn, for his part, notes that "we might put the moral of the last section in a slogan by saying that we should be looking not for truth makers but for assertion licensers" (2013: 270). I believe deflationists can and should take on the truthmaking strategy (though they should still abandon their deflationism on other grounds).

16 See Wright 1992 and Lynch 2009 for a sampling of relevant critiques of deflationism. I have lodged my own criticisms against deflationism elsewhere (Asay 2013a).
} 
consistent with saying that truth is an explanatorily useful concept, one that can be employed in giving analyses of other philosophical notions such as belief, meaning, and assertion (as Davidson, for one, does). The primitivist, then, maintains that truth is both indefinable and substantive, thereby disagreeing with both pluralists and deflationists. Crucially, however, primitivists about the concept of truth need not maintain that truth is in any sense a metaphysically substantive alethic property. As a result, primitivists can completely avail themselves of the truthmaking approach to the metaphysics of truth explored earlier. Truth, for the primitivist, is a philosophically valuable concept, but not a metaphysically potent property. (By way of analogy, one might favor a philosophically robust concept of goodness, though there may be no metaphysically potent property of goodness that corresponds to it.) That the concept of truth and property of truth can be distinguished is a longstanding pillar of certain pluralists' accounts, particularly those who, like Lynch and Wright, maintain that there is a unified concept of truth that is nonetheless associated with a plethora of related alethic properties. The primitivist also thinks that there is a unified concept of truth, but finds no reason to posit any metaphysically active alethic properties.

Here, then, is the suggested alternative to pluralism. Deflationists are correct in thinking that there is no set of metaphysically potent alethic properties that are responsible for making truth-bearers true. But deflationism itself has no answer to the question of what the ontological grounds of truths are. What makes truth-bearers true are the individual members of the world's ontology, which is a matter best explored through the metaphysical lens of truthmaker theory, and not via the theory of truth itself. By way of eschewing alethic properties in favor of traditional truthmakers, this alternative avoids the scope problem, respects the great heterogeneity of truths, and has the resources for developing localized views with respect to realism and anti-realism. What most dramatically separates the view from deflationism is that it accepts that truth is a conceptually substantive and primitive notion, and thus is a view that can get on board with pluralists' (and others') critiques of deflationism. As a result, the conceptual primitivist who adopts traditional truthmaker theory is the theorist of truth best equipped to account for the many phenomena involving truth, from its great heterogeneity to its philosophical importance.

\section{References}

Armstrong, D. M. 2004. Truth and Truthmakers. Cambridge: Cambridge University Press. Asay, Jamin. 2012. A truthmaking account of realism and anti-realism. Pacific Pbilosophical Quarterly 93: 373-394.

—. 2013a. The Primitivist Theory of Truth. Cambridge: Cambridge University Press. 
—. 2013b. Truthmaking, metaethics, and creeping minimalism. Philosophical Studies 163: 213-232.

-. 2014. Against truth. Erkenntnis 79: 147-164.

Bar-On, Dorit, Claire Horisk, and William G. Lycan. 2000. Deflationism, meaning and truthconditions. Philosophical Studies 101: 1-28.

Barnard, Robert, and Terence Horgan. 2006. Truth as mediated correspondence. The Monist 89: 28-49.

Blackburn, Simon. 2013. Deflationism, pluralism, expressivism, pragmatism. In Truth and Pluralism: Current Debates, eds. Nikolaj J. L. L. Pedersen and Cory D. Wright, 263-277. Oxford: Oxford University Press.

Cotnoir, Aaron J. 2013. Validity for strong pluralists. Philosophy and Phenomenological Research 86: 563579.

Davidson, Donald. 1996. The folly of trying to define truth. Journal of Philosophy 93: 263-278.

Dodd, Julian. 2002. Is truth supervenient on being? Proceedings of the Aristotelian Society (New Series) 102: 69-85.

—. 2007. Negative truths and truthmaker principles. Synthese 156: 383-401.

—. 2013. Deflationism trumps pluralism! In Truth and Pluralism: Current Debates, eds. Nikolaj J. L.

L. Pedersen and Cory D. Wright, 298-322. Oxford: Oxford University Press.

Edwards, Douglas. 2011. Simplifying alethic pluralism. Southern Journal of Philosophy 49: 28-48.

Griffith, Aaron M. 2015. Towards a pluralist theory of truthmaking. Erkenntnis 80: 1157-1173.

Haack, Susan. 2005. The unity of truth and the plurality of truths. Principia 9: 87-109.

—. 2014. Nothing fancy: some simple truths about truth in the law. In her Evidence Matters: Science, Proof, and Truth in the Law, 294-323. Cambridge: Cambridge University Press.

Horsten, Leon. 2011. The Tarskian Turn: Deflationism and Axiomatic Truth. Cambridge: MIT Press.

Horwich, Paul. 1990. Truth. Oxford: Basil Blackwell.

—. 1998. Meaning. Oxford: Clarendon Press.

—. 2006. The value of truth. Nô̂s 40: 347-360.

Jarvis, Benjamin. 2012. Truth as one and very many. International Journal of Philosophical Studies 20: 105-114.

Lewis, David. 1983. New work for a theory of universals. Australasian Journal of Philosophy 61: 343377.

—. 2001. Truthmaking and difference-making. Noûs 35: 602-615.

—. 2003. Things qua truthmakers. In Real Metaphysics: Essays in Honour of D. H. Mellor, eds. Hallvard Lillehammer and Gonzalo Rodriguez-Pereyra, 25-42. London: Routledge. 
Lowe, E. J. 2007. Truthmaking as essential dependence. In Metaphysics and Truthmakers, ed. JeanMaurice Monnoyer, 237-259. Frankfurt: Ontos Verlag.

Lynch, Michael P. 2004. Truth and multiple realizability. Australasian Journal of Philosophy 82: 384408.

—. 2006. ReWrighting pluralism. The Monist 89: 63-84.

—. 2009. Truth as One and Many. Oxford: Clarendon Press.

- 2012. The many faces of truth: a response to some critics. International Journal of Philosophical Studies 20: 255-269.

MacBride, Fraser. 2013. For keeping truth in truthmaking. Analysis 73: 686-695.

Moore, G. E. 1899. The nature of judgment. Mind (New Series) 8: 176-193.

Patterson, Douglas. 2010. Truth as conceptually primitive. In New Waves in Truth, eds. Cory D. Wright and Nikolaj J. L. L. Pedersen, 13-29. New York: Palgrave Macmillan.

Pedersen, Nikolaj Jang Lee Linding. 2010. Stabilizing alethic pluralism. Philosophical Quarterly 60: 92-108.

—. 2012. Recent work on alethic pluralism. Analysis 72: 588-607.

—. 2014. Pluralism x 3: truth, logic, metaphysics. Erkenntnis 79: 259-277.

Pedersen, Nikolaj J. L. L., and Cory D. Wright. 2013. Introduction. In their Truth and Pluralism: Current Debates, 1-18. Oxford: Oxford University Press.

Sainsbury, R. M. 1996. Crispin Wright: Truth and Objectivity. Philosophy and Phenomenological Research 56: 899-904.

Sher, Gila. 2004. In search of a substantive theory of truth. Journal of Philosophy 101: 5-36.

—. 2005. Functional pluralism. Philosophical Books 46: 311-330.

Tappolet, Christine. 1997. Mixed inferences: a problem for pluralism about truth predicates. Analysis 57: 209-210.

—. 2000. Truth pluralism and many-valued logics: a reply to Beall. Philosophical Quarterly 50: 382385.

Thomas, Andrew. 2011. Deflationism and the dependence of truth on reality. Erkenntnis 75: 113122.

Williams, Michael. 1999. Meaning and deflationary truth. Journal of Pbilosophy 96: 545-564.

Wright, Cory D. 2012. Is pluralism about truth inherently unstable? Philosophical Studies 159: 89105.

Wright, Crispin. 1992. Truth and Objectivity. Cambridge: Harvard University Press.

—. 1999. Truth: a traditional debate reviewed. Canadian Journal of Pbilosophy Supplementary 24: 31-74. 
Wyatt, Jeremy. 2013. Domains, plural truth, and mixed atomic propositions. Philosophical Studies 166: S225-S236. 